DOI: 10.20472/TEC.2017.004.006

ASIYE KAKIRMAN YILDIZ

Marmara University, Turkey

VAROL SAYDAM

Marmara University, Turkey

\title{
BAHATTIN YALÇINKAYA
}

Marmara University, Turkey

\section{AN ANALYSIS OF PUBLIC LIBRARIES' ABILITY TO REPRESENT PRESCHOOL CHILDREN IN TERMS OF THEIR MISSIONS AND RESPONSIBILITIES}

\begin{abstract}
:
The aim of this study is to emphasise that, in order for reading culture to be instilled and for reading to become a habit in Turkey, not only does reading as an activity need to be instilled in children at preschool level, but to also stress that public libraries need to adopt an active role in the embedding of the notion of the book and reading in the minds of children of preschool age. International standards state that public libraries should devote at least $25 \%$ of their collections, services and activities to children. Within the scope of this study, the efficiency of public libraries in terms of children's services including the library as a space will be examined, in addition to determining the extent to which the preschool period is included in the planning of services. For the purposes of this study, a "current situational analysis" comprising of 20 criteria was undertaken of public libraries operating in 30 different districts of Istanbul. Throughout this process, "Guidelines for Library Services to Babies and Toddlers" prepared by IFLA was used as a reference for questionnaires and research documentation. The research carried out revealed that those public libraries that were effective and efficient in the districts in which they operated in were preferred by preschool children and their families. The results of the study also determined that these libraries were pioneering in terms of promoting reading as a habit and library use, because of the services and activities they provided.
\end{abstract}

\section{Keywords:}

Reading habit, public libraries, preschool period, Turkey

This work was supported by Research Fund of the Marmara University. Project Number: 200716-0385 


\section{Introduction}

According to the literature of the field, public libraries have never been as important as they are today for children and their families. In every corner of today's world, access to information, information literacy and life-long learning now occupy a preferential role in communities (IFLA, 2006). Within this context, public libraries and even more so, children's libraries are the organisations most suited to fulfilling the requirements for such services. According to research carried out, even if families that fall within a low and middle income range possess likeminded values for their children, support for their children educationally varies considerably due to constraints they may face (Celano \& Neumann, 2001). This is particularly true of the early childhood period, if the difficulties faced by low income families, in terms of sending their children to a crèche or kindergarten facility are considered. It could be argued that public libraries could, to some extent, lighten the load of families by providing children of different economic backgrounds with good quality books and a productive environment. Teale (1999) argued that three fundamental activities provided by public libraries were critical for the development of children. These are as follows; reading aloud, creating an enjoyable environment for children and incorporating reading and writing into games. Studies show that reading aloud is the most important activity in terms of increasing the appetite of children for reading and writing (Sulzby \& Teale, 1991).

In the preschool period a child strives to adapt to its natural and societal environment and to also integrate with the society in which they live in. As a result of this, it is in this period that children begin to acquire basic skills and social behaviours. If the fact that cognitive development primarily occurs in the preschool period is taken into account, realising stimulatory productiveness will assist in the diversification of cognitive experiences. Preschool educational organisations contribute greatly to the development of the child's senses and creativity as a result of their educational live made possible through the provision of environmental conditions of substance (Oktay, 2002). This environment should allow for the creation of a prosperous habitat where the development of creative thinking, problem-solving skills and developing establishing cause and effect relationship skills is fostered. Children's books are one of the parts of this rich environment (Sağlam, 2007).

\section{The Importance of the Preschool Period}

The preschool period child is attentive to all things in its surroundings and can be likened to an efficacious researcher and a curious scientist. Instead of verbally providing explanation, a more educational stance is to ensure that the child actively participates in the formation of the experience or event. Awakening the curiosity of a child for new topics can be achieved through encouraging them to ask questions; briefing them on topics they may find interesting and nurturing their imagination (Oktay \& Polat, 2005). There is certainly a need for kindergarten libraries in order for the above support to be realised. 
Research carried out on this subject has established that the education a child receives in the preschool period has a substantive influence on personal and academic success later on in life. Özen and Yanıklar (2014) cite a study carried out by Bloom, which determined that up to the age of $17,50 \%$ of cognitive development has taken place by the age of 4 . Whereas $30 \%$ of cognitive development is achieved between 4-8 years. However, only $20 \%$ of cognitive development takes place between 8-17 years. Therefore, it is evident that acquiring the basic skills and knowledge during these periods is critical as acquiring them later on in life is extremely difficult.

Another study has proven that children who have good reading comprehension and possess a good vocabulary, have more of an opportunity to read more books and to continually better themselves, than their counterparts who do not (Mol \& Bus, 2011). According to the study in question, preschool children who are introduced to children's books with pictures, magazines and publications are $12 \%$ better at spoken language than their counterparts who have not been introduced to such materials. Such children are ahead in terms of these skills by $13 \%$ at primary school, $19 \%$ at middle school, $30 \%$ at high school and $34 \%$ at university level respectively. In a similar vein, it is also anticipated that those who enjoy reading and have a culture for reading, have more advanced verbal and written communication skills than their counterparts, who do not partake in the above (Mol \& Bus, 2011).

The preschool period is the period in which the rate of brain development and the forming of synaptic links is at its most intense and rapid. The development of the brain builds a strong foundation for the child's cognitive, linguistic, motor, social and emotional development. This is why children, particularly in the first six years of their lives in what is known as the preschool period, grow at an unprecedented rate and rapidly mature in such developmental areas. Thus, this leads the way for a child to realise their own potential and to be a productive member of society. The brain is at its most receptive to environmental influences because it develops rapidly throughout the preschool period. Within this framework, it deeply influences a child's development and learning motivation. This is closely related to how much a child can discover, what they can learn and the pace they can learn at, how supportive the child's environment is and the means available to the child. (Okul Öncesi Eğitimi Programı, 2013).

Particularly in the 2000s, in line with the rest of the world, preschool education began to gain status as an important current topic in Turkey also. This period witnessed the necessary legal arrangements being made in Turkey by the government and the Ministry of Education (MoE) to ensure that preschool education was not only supported, but that it became more widespread (Okul Öncesi Eğitimin Güçlendirme Projesi, 2013). Despite the fact that steps are being taken to increase the rate of preschool schooling, it is critical that in parallel to endeavours to increase the rate of schooling, that emphasis should be on supporting and raising the quality of services that are provided. In today's society, libraries constitute one of the communication and social projects of many metropolitan and local authorities and it could be argued that libraries can become 
important visual symbols of a cities. Securing library attendance and ensuring that resources are utilised, depends as much on the number of libraries and technological equipment as it does on library management. Therefore, it is necessary to treat the developmental educational process of librarianship and the transmission process as a whole.

Public libraries which are also referred to as "The University of the People," are obligated to provide information to everybody regardless of age, gender, educational background. Public libraries can be considered to be one of the most important institutions not only for societal progress but also in terms of the development of democratic cultures. Public libraries through contributing to the development of societies' cultural development also play a significant role in the solution to the problem of reading being acquired as a habit. It is imperative that public libraries are utilised in order for reading as a habit to be instilled, developed and sustained in society. However, in order for this to be realised, first the role of public libraries in relation to the acquirement of reading as a habit needs to be defined and the mode of implementation agreed. The Turkish ministry is currently developing new policies and strategies in order to increase the rates of reading as a habit and library use in Turkey, because current rates are not at a desirable level.

Public libraries are institutions that play a role in preparing communities for the future and at the same time represent every strata of society. Public libraries have a special duty to instil reading, to provide support during this process and to ensure that children are provided with books and other media. Preschool children, who are the future of not only their own country but of the world also, can be considered to be the most significant audience for public libraries within this framework of responsibility.

The preschool period is the period in which the child expends effort to conform to its social environment and to that end begins to learn a number of basic skills and social behaviours. If we consider that the majority of cognitive development occurs in the preschool period, acquiring a wealth of stimulation will assist in the diversification of cognitive experiences. This can be achieved through awakening the curiosity of a child for new topics, encouraging them to ask questions, briefing them on topics they may find interesting and nurturing their imagination. İn order for such support to be provided to children, it is imperative that they are introduced to libraries starting from the preschool period.

Unfortunately, including in the preschool period, all children do not have equal access to opportunities and possibilities. This is why educational activities should not be restricted to formal classroom education. Hence there is also a need for education providers in addition to existing educational institutions. It is at this juncture that public libraries play a fundamental role. It is foreseen that public libraries in Turkey can serve to close the gap between children of different socio-cultural backgrounds by increasing the levels of reading and library use, which are currently not at desirable levels. Through accessing public libraries, a worthwhile opportunity exists for 
children from different socio-cultural backgrounds to come together in a unique area with specially designed programmes. This serves to equalise the academic development indicators between children and to reduce structural vulnerabilities.

\section{An analysis of the ability of public libraries in Istanbul to represent preschool children in terms of their missions and responsibilities}

This study focuses on Istanbul which has a population of approximately 15 million and is Turkey's most populated and cosmopolitan city. The ability of public libraries in Istanbul to represent preschool children in terms of their missions and responsibilities was analysed, based on the factors below:

1- Do libraries encourage early learning?

2- Do library staff have experience relating to preschool period children and of providing such a service?

3- The appropriateness of libraries as a space for preschool period children.

4- The adequacy of Library materials and collections for preschool period children.

5- The provision of information services, user guidance and educational/cultural activities by libraries.

This study is the product of a process that comprised of 3 stages and utilised a qualitative method:

1- The identification of problems.

2- The analysis of problems and a determination of where problems generally manifest.

3- The formulation of unique solutions to problems.

The number of public libraries in Istanbul that operate under the Ministry of Culture and Tourism is 34. However, due to the fact that some of these libraries are not in a position to collect data, only 30 libraries have been included in the current study. The questionnaires used in the study comprised of 20 criteria within the context of 5 factors. Throughout the study, a questionnaire was taken to each library respectively by a researcher, who personally ensured that librarians filled them in. As a result of this, it could be argued that the validity and trustworthiness of the answers provided could not be called into question. 


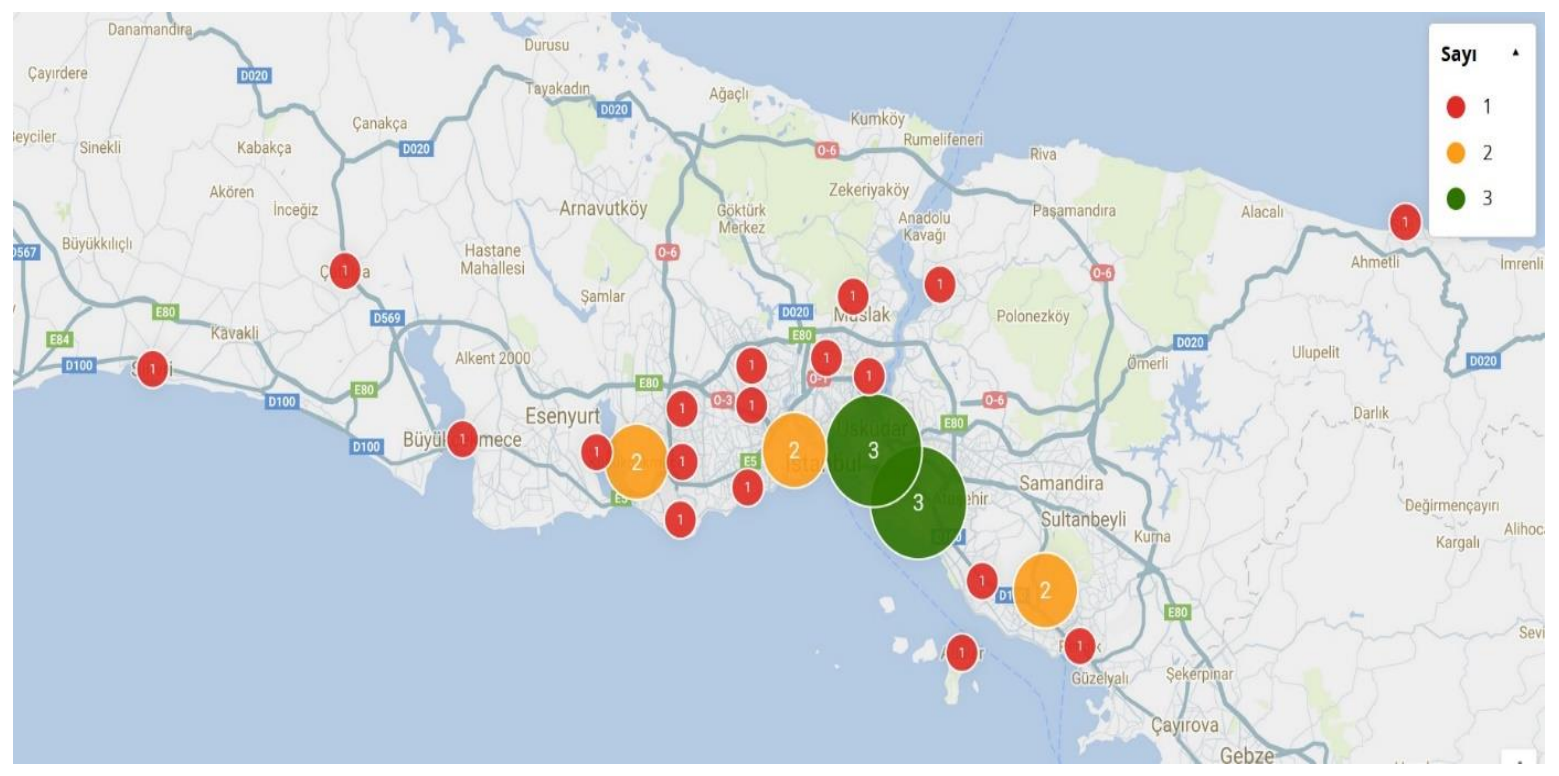

Figure 1- The Concentration of Public Libraries in Istanbul according to Residential District

\subsection{The Descriptive Statistics of the Research}

The forms used for the collection of data were devised using the "Guidelines for Library Services to Babies and Toddlers" prepared by IFLA as a reference source. Accordingly the forms comprised of 20 criteria grouped under 5 factors. Criteria numbered 2 \& 3 were examined under factors $4 \& 5$. The data collection forms were prepared in accordance with the 5 point likert scale. In terms of the evaluation of the criteria found on the forms and with the aim of determining which level the library's responses should be evaluated at, the following expressions were used:

1.No work has been carried out on this topic.

2. Requirements are being determined on this topic.

3. This topic is currently on our agenda/at planning stage.

4.We are currently at implementation stage with regard to this topic..

5. We have completed the process of implementation with regard to this topic.

At the end of the study the data collected was analysed using the SPSS 22.0 programme. $\mathrm{Bu}$ The factors interrogated within the scope of the research and the criteria interrogated in relation to the factors are as follows:

\section{Factor 1: Do libraries encourage early learning?}

Criterion 1- Preschool period children are provided with high quality service and work is carried out to encourage early learning.

Criterion 2- Reading and story time hours for preschool period children are organised.

Criterion 3- Families and preschool period children are encouraged to frequent libraries regularly and to view them as a place to both have fun and to learn. 
Criterion 4- Global best practices are kept abreast of and new ideas that are beneficial to families and children are implemented.

Criterion 5- Preschool period children are kept in mind when service policies are formulated.

Factor 2: Experience of library staff relating to preschool period children and of providing such a service

Criterion 1- The library employs qualified staff that previously worked at an organisation that provided a service for preschool period children.

Criterion 2- Library staff attend various training sessions to develop themselves on the topic of preschool period children.

Criterion 3- Services geared towards adults such as parenting education and lifelong learning are provided.

Criterion 4- Activities that encourage families to visit the library with their children are arranged.

Factor 3: The appropriateness of libraries as a space for preschool period children.

Criterion 1- The space within the library reserved for preschool period children is sufficient. Criterion 2- There is a seating area/recreation area specifically for preschool period children. Criterion 3- There are illustrated signs to direct preschool period children within the library.

Criterion 4- The library building is stroller friendly.

\section{Factor 4: The adequacy of library materials and collections for preschool period children}

Criterion 1- A collection of publications specifically for preschool period children is available. Criterion 2- Material appropriate for age groups such as games, printed materials, multimedia and tools of different formats compatible with the latest technology is provided. Criterion 3- The expectations and requests of the local community are taken into account in the improvement of the library (collection, materials, furniture, computer etc.).

\section{Factor 5- The provision of information services, user guidance and educational/cultural activities by libraries for families.}

Criterion 1- To ensure that both preschool period children and their families are easily able to access library cards and other such benefits.

Criterion 2- To arrange different activities and programmes appropriate for the age group at different times of the day and on certain days of the week to ensure that current users frequent the library more often.

Criterion 3- Striking and informative leaflets are prepared and distributed to encourage families to take preschool period children to the library.

Criterion 4- Expert speakers are invited to speak on parenting skills, preparing for primary school and other fields of interest aimed at developing skills and knowledge. 
Table 1 - Distribution according to the factors of research questions

\begin{tabular}{lll}
\hline Factor & $\begin{array}{l}\text { Criterion } \\
\text { Number }\end{array}$ & $\begin{array}{l}\text { Criterion } \\
\%\end{array}$ \\
\hline F1: Libraries encouraging early learning & 5 & 22,73 \\
$\begin{array}{l}\text { F2: Experience of library staff and providing such a } \\
\text { service }\end{array}$ & 5 & 22,73 \\
$\begin{array}{l}\text { F3: Appropriateness of libraries as a space for } \\
\text { preschool period children. }\end{array}$ & 3 & 13,64 \\
$\begin{array}{l}\text { F4: Adequacy of library materials and collections } \\
\text { for preschool period children }\end{array}$ & 3 & 13,64 \\
$\begin{array}{l}\text { F5: Provision of information services, user guidance } \\
\text { and educational/cultural activities for families. }\end{array}$ & 6 & 27,27 \\
\end{tabular}

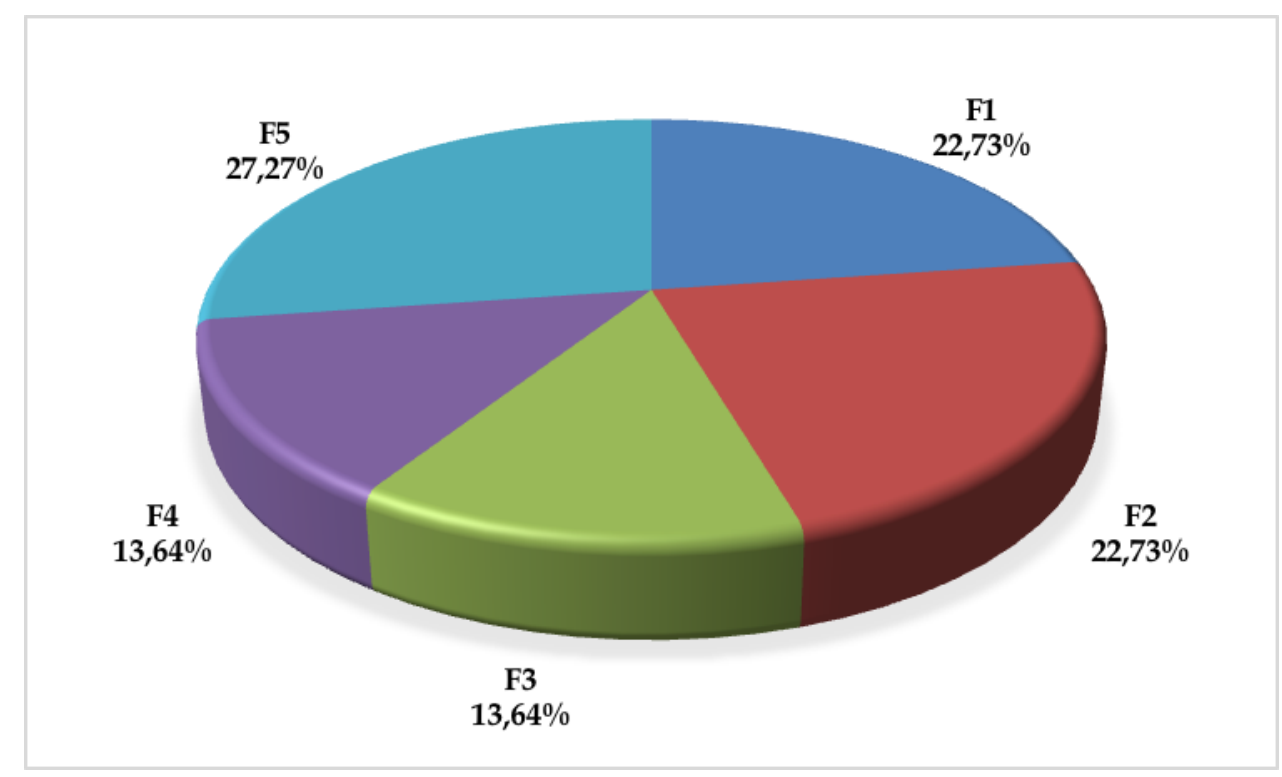

Graphic 1 - The proportional distribution according to the question factors in research

\subsection{The Analysis of Factors and Criteria}

The analysis of the factor that measured whether public libraries in Istanbul supported the early learning skills of preschool period children or not, revealed that the mean level for this factor was $(X=3,16)$. Upon examination of the results, it can be seen that $40 \%$ of the public libraries in Istanbul exhibit a positive stance in terms of encouraging early learning. Whereas in contrast, $30 \%$ display a negative stance. The remaining $30 \%$ of libraries are at planning stage. It is anticipated that with the implementation of their early learning 
programmes, that the public libraries currently at planning stage will demonstrate a considerably more positive outlook on early learning.

Table 2- F1: Descriptive statistics in relation to libraries encouraging early learning

\begin{tabular}{lcccc}
\hline & $\mathbf{N}$ & $\%$ & $\overline{\mathrm{x}}$ & $\mathbf{s s}$ \\
\hline 1. No work has been carried out. & 2 & 6,7 & & \\
2. Requirements are in process of & 7 & 23,3 & & \\
being determined. & & & & \\
3. Is on agenda/planning is being & 9 & 30,0 & 3,16 & 1,14 \\
undertaken & 8 & 26,7 & & \\
4. At implementation stage. & 4 & 13,3 & & \\
5. Process has been completed. & $\mathbf{3 0}$ & $\mathbf{1 0 0}$ & & \\
\hline Total & & &
\end{tabular}

The analysis of the factor that measured whether librarians employed in the public libraries in Istanbul were experienced working with preschool period children or not and an analysis of the provision of service, revealed that the mean level for this factor was $(X=2,4) .60 \%$ of public libraries in Istanbul stated that they were not yet at implementation stage in terms of providing a better service for children. In contrast, only $23.4 \%$ displayed a positive position with regard to this factor.

Table 3 - F2: Descriptive statistics in relation to staff and service quality

\begin{tabular}{lcccc}
\hline & $\mathbf{N}$ & $\%$ & $\overline{\mathrm{x}}$ & $\mathbf{s s}$ \\
\hline $\begin{array}{l}\text { 1. No work has been carried out. } \\
\text { 2. Requirements are in process of }\end{array}$ & 9 & 30,0 & & \\
being determined. & & & & \\
3. Is on agenda/planning is being & & & 2,4 & 1,27 \\
undertaken. & & & & \\
$\begin{array}{l}\text { 4. At implementation stage. } \\
\text { 5. Process has been completed. }\end{array}$ & & & \\
\hline Total & $\mathbf{3 0}$ & $\mathbf{1 0 0}$ & & \\
\hline
\end{tabular}

Upon analysis of public libraries in Istanbul as a space, the mean level for this factor based on analysis results was $(X=2,9)$. It was found that $60 \%$ of public libraries in Istanbul were inadequate as a space for preschool period children. Whereas $40 \%$ of those libraries surveyed stated that their space was adequate for preschool period children. 
Table 4 - F3: Descriptive statistics in relation to libraries' evaluation as a space

\begin{tabular}{lcccc}
\hline & N & $\%$ & $\overline{\mathrm{x}}$ & $\mathbf{s s}$ \\
\hline 1. No work has been carried out. & 6 & 20,0 & & \\
$\begin{array}{l}\text { 2. Requirements are in process of } \\
\text { being determined. }\end{array}$ & 10 & 33,3 & & \\
3. Is on agenda/planning is being & 2 & 6,7 & 2,9 & 1,51 \\
undertaken & 5 & 16,7 & & \\
4. At implementation stage. & 7 & 23,3 & & \\
5. Process has been completed. & $\mathbf{3 0}$ & $\mathbf{1 0 0}$ & & \\
\hline Total & &
\end{tabular}

An analysis of the adequacy of library materials and collections for preschool period in Istanbul's public libraries revealed the mean to be $(X=3,63)$. Whilst $23.3 \%$ of the public libraries in Istanbul were evaluated as inadequate in terms of materials and collections, $20 \%$ of libraires had started making some progress in relation to this factor. $56.7 \%$ of libraries stated that they were adequate in terms of the materials and collections held. When public libraries complete their work to bring their materials and collections up to the level required, it is anticipated that the number of public libraries demonstrating a positive result will increase.

Table 5 - F4: Descriptive statistics in relation to materials and collections

\begin{tabular}{|c|c|c|c|c|}
\hline & $\mathbf{N}$ & $\%$ & $\overline{\mathrm{X}}$ & ss \\
\hline 1. No work has been carried out. & 3 & 10,0 & & \\
\hline $\begin{array}{l}\text { 2. Requirements are in process of } \\
\text { being determined. }\end{array}$ & 4 & 13,3 & & \\
\hline $\begin{array}{l}\text { 3. Is on agenda/planning is being } \\
\text { undertaken }\end{array}$ & 6 & 20,0 & 3,63 & 1,4 \\
\hline 4. At implementation stage. & 5 & 16,7 & & \\
\hline 5. Process has been completed. & 12 & 40,0 & & \\
\hline Total & 30 & 100 & & \\
\hline
\end{tabular}

An analysis of the provision by libraries of information services, user guidance and educational/cultural activities for families revealed the mean to be $(X=3,06) .43 .3 \%$ of the public libraries in Istanbul stated that they were not at an acceptable level with regard to this factor and only $40 \%$ of libraries stated that they were at implementation stage. 
Table 6- F5: Descriptive statistics in relation to information services, user guidance and educational/cultural activities

\begin{tabular}{lcccc}
\hline & $\mathbf{N}$ & $\%$ & $\overline{\mathrm{x}}$ & ss \\
\hline 1. No work has been carried out. & 1 & 3,3 & & \\
$\begin{array}{l}\text { 2. Requirements are in process of } \\
\text { being determined. }\end{array}$ & 12 & 40,0 & & \\
$\begin{array}{l}\text { 3. Is on agenda/planning is being } \\
\text { undertaken }\end{array}$ & 5 & 16,7 & 3,06 & 1,17 \\
$\begin{array}{l}\text { 4. At implementation stage. } \\
\text { 5. Process has been completed. }\end{array}$ & 8 & 26,7 & & \\
\hline Total & $\mathbf{3 0}$ & $\mathbf{1 0 0}$ & & \\
\hline
\end{tabular}

\subsection{An analysis of issues and results}

An analysis of the ability of public libraries in Istanbul to represent preschool children in terms of their missions and responsibilities was reflected in the same table (see Table 8 below) using two mean types. The first mean type employed was the arithmetic mean $(\bar{x})$ and the second type chosen was the median mean (Mdn.). The close proximity of both mean types is striking in terms of illustrating the level of trustworthiness of the research data.

An analysis of the ability of public libraries in Istanbul to represent preschool children in terms of their missions and responsibilities determined the following: libraries encouraging early learning $(F 1)$ mean $(X=3,22)$, experience of library staff and providing such a service ( $F 2)$ mean $(X=2,63)$, libraries as a space (F3) mean ( $\mathrm{X}=2,90)$, adequacy of procuring library materials and collections (F4) mean $(X=3,47)$ information services, user guidance and educational/cultural activities for families (F5) mean $(X=3,03)$. A consideration of the averages as a whole reveals that public libraries throughout Istanbul are yet to fulfil the implementation process in terms of representing preschool children in terms of their missions and responsibilities.

Table 8- An analysis of the ability of public libraries throughout Istanbul to represent preschool children in terms of their missions and responsibilities

\begin{tabular}{lcccc}
\hline Factors & N & $\overline{\mathrm{x}}$ & Mdn. & SS \\
\hline F1 - Libraries encouraging early learning & 30 & 3,22 & 3,10 & 1,00 \\
F2 - Staff and service quality & 30 & 2,63 & 2,50 & 1,02 \\
F3 - Libraries as a space & 30 & 2,90 & 2,33 & 1,33 \\
$\begin{array}{l}\text { F4 - Procuring of materials and } \\
\text { collections }\end{array}$ & 30 & 3,47 & 3,67 & 1,18 \\
$\begin{array}{l}\text { F5 - Information services, user guidance } \\
\begin{array}{l}\text { and educational/cultural activities for } \\
\text { families. }\end{array}\end{array}$ & 30 & 3,03 & 3,00 & 0,99 \\
\hline
\end{tabular}


Results demonstrate that public libraries have reached a certain level of proficiency with regard to the encouragement of early learning and that work with regard securing improvement is being undertaken. Despite the fact that public libraries are not at the desired level in terms of the above, the rise of awareness and the comprehension of the importance of the issue can be evaluated as a positive development. However, it can be observed that serious issues exist with regard to the librarians who will be charged with realizing the above in terms of the provision of service for preschool children. Indeed, $60 \%$ of libraries did not achieve good results on this issue. Preferring librarians who as a minimum prerequisite have experience of working with preschool period children or possess the equivalent to a Postgraduate Certificate in Education (PGCE) would raise the level and quality of service provided.

An evaluation of the appropriateness of libraries as a space for preschool period children in terms of facilities reveals an average outlook. $53 \%$ of libraries did not achieve positive results whilst $47 \%$ of libraries took the view their library as a space was adequate for preschool period children.

An analysis of the ability of public libraries in Istanbul to represent preschool children in terms of their missions and responsibilities concerning the number of collections and materials and their quality was observed at a very high level. The results revealed that $57 \%$ of libraries had either completed or were about to complete their process with regard to the above. In addition to this, $20 \%$ of libraries had this topic on their agenda and were planning changes. Generally speaking, $77 \%$ of libraries exhibited a positive stance which demonstrates that publications for preschool period children in public libraries are widely available. However, the primary issue stems from the fact that preschool period children are not taken into account when libraries formulate their services and policies. Thus, when awareness is raised on this issue, it is possible to make revisions to collections and to ensure the addition of new publications. However, it is more difficult to make changes to the physical space of the library or to staffing if preschool period children have not previously been factored into corporate policies and strategies. An examination of the results reveals that current issues tend to focus on these shortcomings.

\section{Conclusion}

Ensuring the continual development of children and youth is fundamental to ensuring their healthy development and that they also achieve their true potential. As a result of the study undertaken, which aimed to have an impact on all segments of society starting from preschool age, the results will carry significance in the long term and will impact on the learning environment of children in the future. 
The study undertaken showed that preschool period children and families were keen to take advantage of the services and activities offered by public libraries. However, even though the number of users for libraries that offered a good quality service was high, the number of library users where the level of service was not at a desirable level remained low.

As can be seen from the results of the research carried out, public libraries in Istanbul are beginning to consider preschool period children in their policies and strategies. In addition to this, the number of preschool period collections for children is above average. Though the lack of staff in public libraries that have experience working with preschool period children poses a serious issue.

There are public libraries in Istanbul that are ideal in terms of catering for the needs of preschool period children. However, there are also public libraries in Istanbul that are not designed to take into account the needs of preschool period children. Despite this, most libraries are working on the issue and at the very least are including the topic of preschool period children on their agendas and are making plans accordingly. The increase in awareness of the needs of preschool period children is also due to the importance given to the issue by the Ministry of Education and the strides made by public libraries can also be attributed to government policy. It is clear that the ability of public libraries in Istanbul to represent preschool children in terms of their missions and responsibilities will increase.

\section{References}

Celano, D. ve Neumann, S.B. (2001). The role of public libraries in children's literacy development. Pennsylvania, PA: Pennsylvania Library Association.

IFLA. (2006). Guidelines for children's libraries serviceses, http://www.ifla.org/VII/s10/pubs/Childrens Guidelines.pdf

Mol, Suzanne ve Adriane G. BUS (2011) "To read or not to read: a meta-analysis of print exposure from infancy to early adulthood" http://www.ncbi.nlm.nih.gov/pubmed/21219054.

Oktay, Ayla (2002). Yaşamın Sihirli Yılları: Okul Öncesi Dönem. İstanbul: Epsilon

Oktay, Ayla ve Özgül POLAT UNUTKAN (2005). "Okul Öncesi Eğitimin Temel İlkeleri”, Okul Öncesi Eğitim Denetim Rehber Kitabı içinde,ss. 36- 48. YA-PA Yayınları, İstanbul.

Okul Öncesi Eğitimi Programı (2013). Milli Eğitim Bakanlığı Temel Eğitim Genel Müdürlüğü, Ankara.

Özen Altınkaynak, Şenay ve Cengiz Yanıklar (2014). "Anne ve Babaların Okul Öncesi Eğitime Devam Eden Çocuklarının Gelişimine Yönelik Beklentileri”, Mehmet Akif Ersoy Üniversitesi Eğitim Fakültesi Dergisi, 30: $56-72$. 
Sağlam Gündüz, Ayşegül (2007) Anne- Baba ve Öğretmenlerin Okul Öncesi Çocuk Kitaplarını Değerlendirmesi. Yayımlanmamış Yüksek Lisans Tezi. Afyonkarahisar Kocatepe Üniversitesi Sosyal Bilimler Enstitüsü, Afyonkarahisar.

Sulzby, E., \& Teale, W. (1991). Emergent literacy. In R. Barr, M. L. Kamil, P. B. Mosenthal, \& P. D. Pearson (Eds.), Handbook of reading research (Vol. 2, pp. 727-757). New York: Longman.

Teale, W. (1999). Libraries promote early literacy learning: ideas from current research and early childhood programs. Journal of Youth Services in Libraries, 12(2), 9-16. 